\title{
COMPETENCE-BASED EDUCATION CONTENT FORMING MODALITY FOR FUTURE JUNIOR SPECIALISTS OF CONSTRUCTION AND AUTO INDUSTRIES
}

\author{
Tetiana Pashchenko ${ }^{1}$, Nataliia Vanina ${ }^{2}$,
}

$1 \mathrm{PhD}$ in Pedagogy, Senior Researcher, Senior Research Fellow Laboratory of scientific and methodological support training of specialists in colleges and technical schools Institute of Vocational Education and Training of NAES of Ukraine http://orcid.org/0000-0002-7629-7870 e-mail: tantarena@ukr.net

$2 \mathrm{PhD}$ in Economics, Senior Researcher, Senior Research Fellow Laboratory of scientific and methodological support training of specialists in colleges and technical schools Institute of Vocational Education and Training of NAES of Ukraine http://orcid.org/0000-0001-8310-5139 e-mail: nvanina.science@gmail.com

\begin{abstract}
The article is devoted to the formation method of the education content of future associate specialists in the construction and engineering fields in terms of competency that is indicated in the standard.

The goals of the professional training of a future associate specialist are defined in accordance with the outcome of the education process and are displayed in the education content. The general purpose of education, particularly professional is defined by the society, it is declared in educational standards and displayed in educational programs, curriculum, syllabuses of training programs, etc.

The formation of professional competence of a technical college graduate requires optimization of educational process taking into consideration initial vocational, educational, and personal potential, implementation of the most acceptable (scientifically based and didactically feasible) choice of education methods and technologies, as well as compliance with didactic laws and principles.

The article analyzes the requirements for designing of training content, the main components of the formation of the content of education, the principles of designing the content of competence-oriented training of future junior specialists.

The implementation basis of the competence approach is the usage of pedagogical techniques or methods that guarantees the achievement of the planned educational results (consequently, these planned results should be clearly and specifically reflected in the standards of education). Such technologies should envisage learning with action: students perform not artificial, but real practical tasks (projects), gain experience, learn both from teacher, and each other, solve puzzling production and technological cases.

The model of competency of a specialist should be a list of required competences which should graduate of an educational institution be able to use, what professional functions a graduate should be prepared for and what should be the level of his preparedness to performance of specific functions.

Today, it is not enough to implement a set of techniques and training methods, even interactive or creativesearch, to achieve the goals that were set. The fact is that a new educational concept, which is based on a competent approach, requires genuine educational outcomes, a specific and approachable achievement of learning goals. The implementation of standards requirements by means of pedagogical techniques is the subject of the article.
\end{abstract}

Keywords: education content, future associate specialists of the construction and engineering industries, competency approach, learning technologies. 
Introduction. The importance of professional advance education is the preparation of students for their participation in socio-cultural and professional activities, the formation of their philosophy, the development of a system of values and ideals that determine each individual's social position, attitude to the world and determination of his place in it.

The orientation of the educational process on the training of associate specialists who are capable of taking responsibility in the most difficult situations requires review and improvement, first of all, of process' content. In accordance with the main directions of modernization of education, the specialists content training must meet the requirements of a competent approach that ensures that a graduate will be able to implement all elements of his training in direct professional activity.

Materials. The study of the design of the content of education, of its effectiveness, relatively to the actual level of it and prospects of the development of society, the issues of modernization of the education content are reflected in the articles of V. Andrushchenko, V. Babak, O. Belova, A. Verbitsky, O. Kovalenko, Y. Fokin and others.

Requirements, principles, factors, criteria for selection of education content are offered by Yu. Babansky, N. Volkova, V. Voronov, O. Zheleznyakova, N. Moiseyuk, N. Nikitina, M. Petukhov, M. Fitsula, D. Chernilevsky and others.

But, the methodology of forming the education content for future associate specialists in the construction and engineering sectors that is accordingly indicated in the competence standard together with numerous researches, remained out of the zone of the scientists' attention.

The purpose of the article is to research the formation methodology of a content of a future associate specialists education according to competencies mentioned in the standard.

Methods. Such research methods were used accordingly to author's idea to reach the stated goal and to solve tasks, as theoretical - analysis of psychological and pedagogical literature relevant with the topic, for researching the status of the problem in pedagogical theory and practice; analysis, synthesis, abstraction, generalization for studying the formation methodology of a content of a future associate specialists education according to competencies mentioned in the standad.

Results and discussions. Main principles of the education content formation are the conformity of all its elements and of all levels of the society needs; the unity of the content and procedural aspects of learning; the structural unity of the education content at different levels of its formation in development from general to more specific and, finally, to the concrete forms of its implementation through the process of learning (Chernilevsky, 2008).

The foundation of the higher education standards of the new generation is the competence approach. The competent approach application to the development of the IED should lead to the creation of a new system of diagnostic tools with the transition from assessment of the graduate's knowledge to the evaluation of his competencies and the determination of the competence level in general (Methodological Recommendations for the Development of the Components of the Branch Standards for Higher Education (Competence Approach), 2013).

The determination of the volume and content of the obligatory knowledge of each discipline at a stated degree of learning, forms, methods and organization tools of assimilation and independent creative development in accordance with the list of competencies and learning outcomes that are specified in the standards will become the main tasks for the educational institutions in the process of designing the content of the pedagogical process.

The competence of associate construction and engineering specialists should cover elements of the functional and humanitarian direction of professional training, which determine the practical formation and development of the specialist's personality as a whole.

The vast majority of scientists considering the education content first-of-all highlight, the so-called key (over professional) competencies.

These competencies are supported by certain abilities, such as critical thinking, creativity, "European dimension" and active life attitude. Together, these abilities contribute to the development of a personality. In modern conditions the social significance of the profession and, therefore, an understanding of the position in the social relations and the ability for critical evaluation of life and professional experience, conscious choice of ways and improvement methods of personal and professional qualities should be of the greatest importance for graduates to understand.

The conformity of the quality of graduates' training with the requirements of the corresponding industry standard of the higher education should be determined with socio-personal, general scientific, instrumental and professional competencies.

Professional competencies are generallyprofessional and specialized-professional they may have a generalized character that is inherent to a professional, specialist or a certain class (subclass, group) of professions, and are also determined by the requirements of specific professional standards for a particular profession or (in their absence) by employers with their expertise, responsible for the development of the specified professional standards.

The formation of a professional competence of a graduate of a technical college who is an associate 
construction specialist requires the optimization of the educational process, considering the initial vocational and personality potential, the implementation of the most acceptable (scientifically based and didactically feasible) choice of education methods and technologies, as well as compliance with didactic laws and principles.

The formation of a professional competence should be done considering knowledge, abilities, skills and professional qualities that already exist. The process of an active professional-personal development of associate construction specialists should be optimized at each stage of a professional training in a technical college.

The goals of the professional training of a future associate specialist are determined in accordance with the final results of the training and are reflected in the education content. The purpose of education, particularly professional, is determined by the society, it is declared in educational standards and reflected in educational programs, curriculum, syllabuses of training, etc.

The content design of the training of future associate specialists should take into account such requirements:

$\checkmark$ content at all training stages should be aimed at the realization of the main goal of a specialist training and based on scientific principles;

$\checkmark$ to comply with the logic and system that is inherent to one or another field of scientific knowledge;

$\checkmark$ to consider the relationship between selected educational disciplines;

$\checkmark$ to reflect the connection between the theory and the practice;

$\checkmark$ to comply with age and psycho-physical capabilities of students;

$\checkmark$ to promote the mastering of general-cultural and professional-pedagogical level of the preparation of an associate specialist;

$\checkmark$ to be carried out on a fundamental, cultural and humanistic basis;

$\checkmark$ to comply with modern didactic requirements;

$\checkmark$ to be focused not only on the training of an associate specialist of the present but also of the future.

The main components of the building of the education content by N. Kovalenko (1995) are:

$\checkmark$ content sources, social experience, which includes content and procedural components at each level of the society development;

$\checkmark$ factors that influence the education content;

$\checkmark$ principles of the education content selection as methodological elements of the guidance system in the content selection process;

$\checkmark$ criteria as direct tools for determination of the specific content of the training material; $\checkmark$ methods of content selection for a subject that are inextricably linked to techniques of its building.

Main guiding principles that show what does need and what does not need to be included in the education content are the basis of the content designing for competence-oriented training of future associate specialists: the scientific principle; sequence and continuity principles; the diagnostic goal-setting principle, the principle of the accordance of education with the requirements of society, science, culture and personality; the principle of the unity of the content and procedural aspects of learning; the principle of the accessibility of the education content; the principle of the education content compliance with the goals of the chosen education model; the principle of fundamentalization of the education content; the principle of humanizing the education content; the principle of the structural unity of the education content at different levels of community and at the interdisciplinary level; the principle of taking into consideration the content and procedural aspects of learning during the formation and design of the content of educational material.

The implementation basis of the competence approach is the use of pedagogical techniques or techniques that guarantee the achievement of the planned educational outcomes (consequently, these planned results should be clearly and specifically reflected in the education standards). Such technologies should envisage learning with action: students perform not artificial, but real practical tasks (projects), gain experience, learn both from teacher, and each other, solve puzzling production and technological cases. (Luzan, 2018).

Scientists research the design of the education content at the following levels:

1) the level of higher education standard;

2) the level of educational and professional program;

3) the level of curriculum;

4) the level of the discipline programs;

5) the level of the training module;

6) the level of individual educational tasks.

Taking into account that the design of the content of educational programs, curriculum, discipline programs, training modules, individual educational tasks for students is deeply researched in scientific and pedagogical spheres, I will emphasize attention on the content design of the future associate specialists training according to the competencies that are specified in the standard.

The model of competency of a specialist should be a description of required competences which should graduate of an educational institution be able to use, what professional functions a graduate should be 
prepared for and what should be the level of his preparedness to performance of specific functions.

According to the higher education standard in Ukraine on specialty 192 - "Construction and civil engineering" and specialty 133 - "Sectoral engineering", the list of graduate's competencies consists of three groups:

1) Integral - the ability to solve specialized cases and solve practical tasks in the field of construction and civil engineering, that is characterized with complex and systematic approach, on the basis of the application of basic theories and methods of fundamental and applied sciences.

2) General competencies.

3) Professional competencies of the specialty (PC).

Final, complex and integrative learning outcomes that determine the normative content of the training and correlate with the list of general and special competencies, mentioned above, are approached during the assimilation of the learning material.

Today, it is not enough to implement a set of techniques and training methods, even interactive or creative-search, to achieve the goals that were set. The fact is that a new educational concept, which is based on a competent approach, requires genuine educational outcomes, a specific and approachable achievement of learning goals. Therefore, today we should discuss the fulfillment of standards requirements with the help of pedagogical technologies. Let's briefly cite the main characteristics of this category.

In our work, speaking of the technology of learning, we understand the scientifically grounded, predesigned stage-by-stage organization of the educational process that is being implemented into practice to achieve guaranteed educational results.

The pedagogical technology reflects the model of education and disciplinary processes of an educational institution and combines their content, forms and tools.

The choice of educational technology and the most complex elements of it is of the greatest importance. Verifying the choice, you must take into consideration that every technology is oriented to a specific range of didactic tasks.

It is necessary to evaluate reasonably and creatively the possibilities of specific learning technology, to know its strengths and weaknesses. On this basis, the optimal mesh of technologies relatively to the topic of the training subject and to a specific lesson should be chosen.

Choosing learning technology, following criteria should be considered (Koshuk, 2018):

$\checkmark$ goals, tasks of studying topics, sections;

$\checkmark$ content and character, sequence of mastering the disciplines of the educational program;

$\checkmark$ level of methodological competence of the teacher (teachers); technical equipment of the educational process (means of training);

$\checkmark$ level of educational and cognitive activity of students;

$\checkmark$ external conditions (time, production, economic, etc.);

$\checkmark$ the learning process complexity, ergonomic requirements;

$\checkmark$ the complexity level of the training content.

The achievement levels of students' education should be considered in learning outcomes. The most common mean (tool) for structuring levels of thinking that determine the goals of learning, which is worldwide accepted in the international educational environment is the taxonomy by B. Bloom.

Let's take into consideration how the learning technologies, which are suitable to the specific purpose of studying a section or a topic, are selected.

1. If the goals of a study of a section or a topic do not exceed the level of assimilation, the reproductive learning technology will be appropriate to use. It includes:

$\checkmark$ attentive listening to the teacher;

$\checkmark$ student work with a textbook;

$\checkmark$ observation of investigated objects, phenomena;

$\checkmark$ implementation of practical actions with the instructions of the teacher.

2. If the purpose of the study of a section or a topic is the mastering of the major algorithms of activity, then the technology of training should be reproductivealgorithmic, it means:

$\checkmark$ educational-cognitive activity, including the annotation of the educational material;

$\checkmark$ speeches (reports);

$\checkmark$ solving of typical tasks, participation in didactic games.

3. If goal of a section or a topic study are the development the search, heuristics activity, then it is necessary to choose heuristic teaching technologies, where didactic techniques dominate with using:

$\checkmark$ problematic education;

$\checkmark$ business games, real design;

$\checkmark$ parsing of atypical production cases.

4. If goals of the section, the topic study include the formation of creative technological thinking, then creative learning technologies are necessary to be implemented, they are based on methods of mastering the experience of creative activity:

$\checkmark$ situation of complicated conditions;

$\checkmark$ group solving of creative tasks;

$\checkmark$ group stimulation of creative search ("brainstorming", synectics, method of morphological 
analysis and synthesis of technological decisions, functional and cost analysis, method "TSIT" - the theory of solution of inventive tasks, etc.).

5. If goals of studying a sector, or a topic are creation an informative culture of students, the ability to process information, then innovative information technologies should be applied: automated learning systems; interactive programs; multimedia technology; hypertext technologies; telecommunication projects, etc.

Naturally, the content features of different disciplines significantly differ, that results in the use of different learning technologies.

Let's consider the implementation of learning technology on the example of a studying a specific academic discipline. The major educational objective ("to calculate", "express", "demonstrate", "know", "interpret", "evaluate", "apply", "create") is regulated by the state standard of vocational education and is achieved when specific educational tasks are being performed by a student (Galuzyak, 2007, p. 190).

After assimilating the educational material, the student is being involved in the process of performing the tasks of the reproductive type, and after the diagnosing, if he demonstrates the necessary level of educational achievement, the implementation of more complex educational tasks is envisaged.

It is worth emphasizing that if the purpose of the training is to develop students' abilities to carry out tasks of a creative nature, then tasks of search character are being performed, and problematic or simulation games are being actioned, etc. After each technological stage learning outcomes are diagnosed and, during the thematic control, are compared with "optimistic expectations" it is the general purpose of learning.

For instance, according to the state standard of higher education preparation for a bachelor's degree in the field of Construction and Civil Engineering, the graduate must have "the ability to understand the major theoretical ideas, concepts and principles of mathematical and socio-economic sciences" (project). And, according to the state standard of higher education preparation for a bachelor's degree in the field of "Branch Engineering", the graduate must have "the ability to demonstrate knowledge and understanding of the major ideas of fundamental and engineering sciences that is the foundation of the sectoral engineering. The stated goal is focused on the students' level 1 assimilation of the educational material and does not require further solving of educational tasks.

In return, the formation of a future builder's ability to work with geodetic instruments and to use topographical materials in the design and construction of objects and engineering networks, the formation of a future branch engineering specialist's ability to work with the main sources of technical information, requires students to master the second level of mastering the material (not to imagine, to recognize, to orient, but to specifically work with geodetic instruments or systems of automatic control in mechanical engineering).

By analogy to the reproductive level of knowledge assimilation, the technology of problematic-developing learning provides students with the acquisition of productive, creative learning outcomes and, accordingly, ensures the development of their professional competence.

The methodology of preparation and conduction of the education forms that are part of the structure of problem-developing technology (different types of lessons, independent study, simulation games, project method, etc.), is deeply projected and written out in modern scientific and educational literature.

The application of design technology can provide the formation of the skills to search, to process and to analyze information from various oral, written and electronic sources (competence KZ07); the ability to work in a team, using interpersonal skills (competence KZ08); the ability to learn independently (competence KZ06); knowledge of manufacturing technology, technical characteristics of modern building materials, products and structures, the ability to effectively use them in the design and construction of construction objects (competence $\mathrm{KS} 05$ ) in future builder.

And, for instance, the competence of KS05 will ensure the formation of the ability to operate with physical terms and concepts by recognizing the physical basis of phenomena and processes arising during the operation of machine building products, to apply physical models and patterns in solving problems, to carry out research on physical phenomena and processes in a future mechanical engineering specialist.

For the formation of general competencies, it is necessary to choose such a technology of learning, in which time would be spent mostly independently and students would learn how to plan, organize, self-control and evaluate their actions and activities in general. One of these technologies is a modular approach, which is based on the active educational and cognitive activity of students, which makes it possible to individualize the pace of mastering knowledge.

A modular approach can be used to create general competencies and communication (communication skills and abilities); the ability to solve problems (the ability to plan and perform actions in order to get the expected result); cooperation (the ability to effectively co-operate in a team); self-development (the ability to organize activities, self-knowledge, self-esteem, critical and analytical thinking); compensation readiness (the ability and the skill to overcome the 
difficulties that arise when studying new knowledge), entrepreneurship (ability to design their activities and activities of others); knowledge of information technologies (the ability not only to use well-known technical software information processing, but also the ability to self-development of new ones).

The main task of the teacher is to teach the activities to the learner. This is facilitated by the use of technology of collective mental activity(CMA). This technology is defined as "a continuous process of managing the development of the needs, abilities of those who study."

Methods of creative problem solving: brain attack, synectics, morphological analysis, method of analysis and synthesis of fantastic ideas, method of "garlands associations", strategy of sevenfold search, method of heuristic questions, inversion method, method of empathy (personal analogy), "snowball" method, method of "a carpet of ideas" and others.

Conclusions. Thus, the methodology for designing the main forms of reflection of the content of training of associate specialists on the basis of a competent approach is aimed at achieving the ultimate goal: to select such a content of training, the acquisition of which will ensure graduates of vocational education and training institutions to be demanded and successful in the labor market.

Prospects for further research may be related to the search for psychological and pedagogical conditions for improving the effectiveness of meeting the standards of standards by means of pedagogical technologies.

\section{List of references}

Галузяк, В. М., Сметанський, М. І. та Шахов, В. І., 2007. Педагогіка: навч. посіб. Вінниця: ДП "Державна картографічна фабрика".

Єршова, Л., 2015. Формування референтної особистості як проблема освітньої практики сучасної України. Вісник Черкаського національного університету. Педагогічні науки, 6 (339), с. 119-124.

Єршова, Л., 2018. Трансформація системи цінностей учнівської і студентської молоді в контексті реформування вітчизняної професійної освіти. Науковий вісник Інституту професійно-технічної освіти НАПН України. Професійна педагогіка, 16, с. 162-168.

ИД "Первое сентября", 2003. Гетманская, А.А., 2005. Формирование ключевых компетенций у учащихся, [online] (Останнє оновлення 24 Лютий 2005) Available at: <http://festival.1 september.ru/articles/213541/> (Дата звернення 25 Березень 2019).

Коваленко, Н. Д., 2005. Методы реализации принципа профессиональной направленности при отборе и построении содержсния общеобразовательных предметов в высшей школе. Кандидат наук. Томский государственный педагогический университет.

Кошук, О. Б., 2018. Теоретичні засади застосування інноваційних педагогічних технологій у професійній підготовці інженерів-механіків. Науковий вісник НУБіП України. Серія: Педагогіка, психологія, філософія, [online] 277, с. 129-138. Доступно: <http://journals.nubip.edu.ua/index.php/Pedagogica/article/view/10552> [Дата звернення 25 Березень 2019].

Гуло, В.Л., укл. та ін., 2018. Методичні рекомендації розроблення складових галузевих стандартів вищої освіти (компетентнісний підхід). Київ: Інститут інноваційних технологій і змісту освіти МОН України.

Радкевич, В. О., 2016. Теоретичні та методичні засади розвитку професійної освіти і навчання: результати, проблеми, перспективи. Науковий вісник Інститут професійно-технічної освіти НАПН Украӥни. Професійна педагогіка, 11, с. 5-23.

Радкевич, В. О., 2017. Наукові засади підвищення престижності вітчизняної професійної освіти. Науковий вісник Інституту професійно-технічної освіти НАПН України. Професійна педагогіка, 13, с. 5-14.

Фіцула, М.М., 2006. Педагогіка вищої иколи: навч. посіб. Київ: Академвидав.

Чернілевський, Д.В., 2010. Педагогіка вищої иколи: підручник. Вінниця: АМСКП, Глобус-Прес.

Лузан, П.Г., Пащенко, Т.М., Ваніна, Н.М. та Колісник, Н.В., 2018. Стандартизація професійної освіти на основі компетентнісного підходу Science Rise, 5 (25), с. 32-35.

\section{Translated \& Transliterated}

Haluziak, V. M., Smetanskyi, M. I. ta Shakhov, V. I., 2007. Pedahohika: navch. posib. [The pedagogy]. Vinnytsia: DP "Derzhavna kartohrafichna fabryka, [in Ukrainian].

Yershova, L., 2015. Formuvannia referentnoi osobystosti yak problema osvitnoi praktyky suchasnoi Ukrainy [Forming a reference person as a problem of educational practice in the modern Ukraine]. Visnyk Cherkaskoho natsionalnoho universytetu. Pedahohichni nauky [The Journal of Cherkasy National University. Pedagogy], 6 (339), s. 119-124, [in Ukrainian].

Yershova, L., 2018. Transformatsiia systemy tsinnostei uchnivskoi i studentskoi molodi v konteksti reformuvannia vitchyznianoi profesiinoi osvity [Transforming a system of values for pupils and students in the context of updating the Ukrainian professional education]. Naukovyi visnyk Instytutu profesiino-tekhnichnoi osvity NAPN Ukrainy. Profesiina pedahohika [The Scientific Journal of the Institute for Vocational Education of NAES of Ukraine], 16, s. 162-168, [in Ukrainian]. 
ID "Pervoe sentyabrya", 2003. Getmanskaya, A.A., 2005. Formirovanie klyuchevyih kompetentsiy u uchaschihsya [The formation of students' key competencies], [online] (Ostannie onovlennia 24 Liutyi 2005) Available at: <http:// festival.1september.ru/articles/213541/> (Data zvernennya 25 Berezen 2019), [in Russian].

Kovalenko, N. D., 2005. Metodyi realizatsii printsipa professionalnoy napravlennosti pri otbore $i$ postroenii soderzhaniya obscheobrazovatelnyih predmetov $v$ vyisshey shkole [Methods of a realization of a principle of the professional focus during choosing and building of a content of general education subjects in a high school]. Kandidat nauk. Tomskiy gosudarstvennyiy pedagogicheskiy universitet, [in Russian].

Koshuk, O. B., 2018. Teoretychni zasady zastosuvannia innovatsiinykh pedahohichnykh tekhnolohii u profesiinii pidhotovtsi inzheneriv-mekhanikiv [Theoretical terms for the implementation of innovative, pedagogical techniques in a professional training of engineers and mechanics]. Naukovyi visnyk Natsionalnoho universytetu bioresursiv $i$ pryrodokorystuvannia Ukrainy. Seriia: Pedahohika, psykholohiia, filosofiia [Scientific Herald of National University of Life and Environmental Sciences of Ukraine. Series: Pedagogy, Psychology, Philosophy], [online] 277, s. 129-138. Dostupno: <http://journals.nubip.edu.ua/index.php/Pedagogica/article/view/10552> [Data zvernennia 25 Berezen 2019], [in Ukrainian].

Hulo, V.L., ukl. ta in., 2018. Metodychni rekomendatsii rozroblennia skladovykh haluzevykh standartiv vyshchoi osvity (kompetentnisnyi pidkhid) [Methodological recommendations on the development of components of department standards of a high education (competency approach)]. Kyiv: Instytut innovatsiinykh tekhnolohii i zmistu osvity MON Ukrainy, [in Ukrainian].

Radkevych, V. O., 2016. Teoretychni ta metodychni zasady rozvytku profesiinoi osvity i navchannia: rezultaty, problemy, perspektyvy [Scientific Herald of the Institute of Vocational Education]. Naukovyi visnyk Instytutu profesiino-tekhnichnoi osvity NAPN Ukrainy. Profesiina pedahohika [The Scientific Journal of the Institute for Vocational Education of NAES of Ukraine], 11, s. 5-23, [in Ukrainian].

Radkevych, V. O., 2017. Naukovi zasady pidvyshchennia prestyzhnosti vitchyznianoi profesiinoi osvity [Scientific Herald of the Institute of Vocational Education]. Naukovyi visnyk Instytutu profesiino-tekhnichnoi osvity NAPN Ukrainy. Profesiina pedahohika [The Scientific Journal of the Institute for Vocational Education of NAES of Ukraine], 13, s. 5-14, [in Ukrainian].

Fitsula, M.M., 2006. Pedahohika vyshchoi shkoly: navch. posib. [The pedagogy of a high school]. Kyiv: Akademvydav, [in Ukrainian].

Chernilevskyi, D.V., 2010. Pedahohika vyshchoi shkoly: pidruchnyk [The pedagogy of a high school]. Vinnytsia: AMSKP, Hlobus-Pres, [in Ukrainian].

Luzan, P.H., Pashchenko, T.M., Vanina, N.M. ta Kolisnyk, N.V., 2018. Standartyzatsiia profesiinoi osvity na osnovi kompetentnisnoho pidkhodu [Standardization of a professional education according to a competency principle]. Science Rise, 5 (25), s. 32-35, [in Ukrainian].

\section{Методика формування змісту освіти майбутніх молодших спеціалістів будівельної та машинобудівної галузей за компетентнісним підходом}

\section{Тетяна Пащенко ${ }^{1}$, Наталія Ваніна²,}

1 кандидат педагогічних наук, старший науковий співробітник, старший науковий співробітник лабораторії науковометодичного супроводу підготовки фахівців у коледжах і технікумах Інституту професійно-технічної освіти НАПН України, м. Київ http://orcid.org/0000-0002-7629-7870 e-mail: tantarena@ukr.net

2 кандидат економічних наук, старший науковий співробітник, старший науковий співробітник лабораторії науковометодичного супроводу підготовки фахівців у коледжах і технікумах Інституту професійно-технічної освіти НАПН України, м. Київ http://orcid.org/0000-0001-8310-5139 e-mail: nvanina.science@gmail.com

Реферат. Стаття присвячена методиці формування змісту освіти майбутніх молодших спеціалістів будівельної та машинобудівної галузей відповідно зазначеним у стандарті компетентностям.

Цілі професійної підготовки майбутнього молодшого спеціаліста визначаються у відповідності з кінцевим результатом навчання та відображаються у змісті освіти. Загальну мету освіти, зокрема фахової передвищої, визначає суспільство, вона задекларована в освітніх стандартах та відображається в освітніх програмах, навчальних планах, робочих навчальних програмах дисциплін тощо.

Формування професійної компетентності випускника технічного коледжу вимагає оптимізації освітнього процесу з урахуванням початкового професійно-освітнього та особистісного потенціалу, здійснення найбільш прийнятного (науково обгрунтованого і дидактично доцільного) вибору методів і технологій навчання, а також відповідності дидактичним закономірностям і принципам. 
У статті проаналізовано вимоги проектування змісту підготовки, основні компоненти побудови змісту освіти, принципи проектування змісту компетентнісно орієнтованої підготовки майбутніх молодших спеціалістів.

Основою реалізації компетентнісного підходу є застосування педагогічних технологій або методик, які гарантують досягнення запланованих освітніх результатів (відповідно, ці заплановані результати мають чітко й конкретно відображатися в стандартах освіти). Такі технології повинні передбачати навчання дією: студенти виконують не штучні, а реальні практичні завдання (проекти), набувають досвіду, навчаються як у викладача, так і один в одного, розв'язують проблемні виробничо-технологічні ситуації.

Компетентнісна модель фахівця має являти собою опис того, яким набором компетентностей повинен володіти випускник навчального закладу, до виконання яких професійних функцій він повинен бути підготовлений і яка має бути ступінь його підготовленості для виконання конкретних функцій.

Щоб досягти поставлених цілей, на сьогодні недостатньо використати комплекс методів і прийомів навчання, хай навіть інтерактивних чи творчо-пошукових, оскільки нова освітня концепція, заснована на компетентнісному підході, вимагає достеменних освітніх результатів, конкретного і реального досягнення цілей навчання. У статті йде мова про виконання вимог стандартів засобами педагогічних технологій.

Ключові слова: зміст освіти, майбутні молодші спеціалісти будівельної та машинобудівної галузей, компетентнісний підхід, технологї навчання.

Received: 15 May 2019

Accepted: 11 June 2019 